\title{
Synthesis of Virus-Specific Ribonucleic Acid in KB Cells Infected with Type 2 Adenovirus
}

\author{
JOSEPH J. LUCAS AND HAROLD S. GINSBERG \\ Department of Microbiology, School of Medicine, University of Pennsylvania, Philadelphia, Pennsylvania 19104
}

Received for publication 29 March 1971

\begin{abstract}
By using the technique of deoxyribonucleic acid (DNA)-ribonucleic acid (RNA) hybridization, virus-specific RNA (cRNA) was detected $6 \mathrm{hr}$ after infection in preparations of total RNA from cells infected with type 2 adenovirus in the presence of $2 \mu \mathrm{M} 5$-fluorodeoxyuridine. In the absence of 5-fluorodeoxyuridine, there was a continuous increase in the incorporation of ${ }^{3} \mathrm{H}$-uridine into viral $\mathrm{CRNA}$ until $20 \mathrm{hr}$ after infection, at which time approximately $40 \%$ of the ${ }^{3} \mathrm{H}$-uridine entering RNA was found in virus-specific RNA. When RNA was prepared from polyribosome fractions obtained from cytoplasmic extracts of infected cells, virusdirected transcription was detected at $3 \mathrm{hr}$ after infection (i.e., 3 to $4 \mathrm{hr}$ before the initiation of viral DNA synthesis). Viral cRNA species synthesized at different times after infection were compared by the technique of DNA-RNA hybridizationinhibition ("presaturation" hybridization-competition). Three hybridizationinhibition techniques were compared. The techniques differed in the manner in which the DNA-RNA complex was isolated after the first hybridization reaction. Depending on the procedure employed, various degrees of inhibition were measured. The variation could be essentially eliminated if prior to hybridization the inhibitory RNA species were alkali-degraded to a uniform size of about $4 S$. Undegraded RNA could be used if the DNA-RNA complex was isolated by using a procedure involving rigorous washing (preferably including ribonuclease treatment) before the second hybridization with labeled RNA. When a rigorous hybridization-inhibition procedure was used, three classes of virus-specific RNA species could be distinguished: (i) early RNA class I whose synthesis began prior to viral DNA replication and stopped at some time after the initiation of viral DNA replication-it comprised about $70 \%$ of the early RNA species and was apparently degraded by $18 \mathrm{hr}$ after infection; (ii) early RNA class II whose synthesis began prior to viral DNA replication and apparently continued at an enhanced rate late in infection; and (iii) late RNA whose synthesis began after the initiation of viral DNA synthesis.
\end{abstract}

Introduction of the techniques of deoxyribonucleic acid (DNA)-ribonucleic acid (RNA) hybridization (31) and hybridization-competition (29) permitted detailed studies of the transcription of viral genomes, including those of adenoviruses $(2,26,27,50,51)$. A reinvestigation of the regulation of synthesis of type 2 adenovirusspecific RNA species (cRNA) presented the possibility that the particular hybridization-competition technique employed greatly influences the results obtained. Although, theoretically, the methods of simultaneous and sequential hybridization-competition should yield the same results $(12,38)$, the presaturation hybridizationinhibition technique has been claimed to reveal greater specificity in comparing RNA species from different mammalian cell types $(3,14,48)$.
Hence, to study transcription of virus-specific RNA species in productive and abortive adenovirus infections, it was necessary to make a critical evaluation of the hybridization-inhibition techniques which are commonly used $(22,48,54)$. Data presented here indicate that results are dependent upon the experimental method employed and that a rigorous technique is required.

The evidence presented in this communication indicates that, in type 2 adenovirus infection, viral cRNA synthesis begins by $3 \mathrm{hr}$ after infection and that at $20 \mathrm{hr}$ approximately $40 \%$ of the ${ }^{3} \mathrm{H}$-uridine incorporated into RNA is found in virus-specific RNA. When a rigorous hybridization-inhibition technique was used, it was found that a significant portion of early virus-specific RNA species is not transcribed when late cRNA 
species are synthesized. Those early cRNA species which are also made after the initiation of viral DNA replication appear to be synthesized at an enhanced rate late in infection.

\section{MATERIALS AND METHODS}

Virus and tissue culture. The prototype strain of adenovirus type 2, which had been plaque purified three times, was used in all experiments. KB cells were propagated in Eagle's minimal essential medium (MEM) supplemented with $10 \%$ calf serum $(15,16)$, and at the time of infection the cells were changed to MEM containing $5 \%$ serum. Cells in suspension cultures were infected at an input multiplicity of 100 to 300 plaque-forming units (PFU) per cell. Virus was assayed on monolayers of $\mathrm{KB}$ cells by the plaque assay (36) or fluorescent-focus assay (18). Purification of adenovirus was accomplished by a technique reported earlier (36).

Extraction and denaturation of viral DNA. Viral DNA was extracted as described previously (2) except that the mercaptoethanol step was omitted. The purified DNA was dialyzed against $0.1 \times$ SSC $(1 \times$ SSC is $0.15 \mathrm{M} \mathrm{NaCl}, 0.015 \mathrm{M}$ sodium citrate, $p \mathrm{H} \mathrm{7.0)}$ and denatured by raising the $p \mathrm{H}$ to 12.8 with $1 \mathrm{~N} \mathrm{NaOH}$. After $10 \mathrm{~min}$ at room temperature, the $p \mathrm{H}$ was rapidly adjusted to 7.0 with $1 \mathrm{~N} \mathrm{HCl}$.

Extraction of RNA from KB cells. RNA was extracted from cells by the method of Scherrer and Darnell (47) as modified by Homma and Graham (33). After ethanol precipitation, the RNA was extensively dialyzed against $2 \times$ SSC, frozen at $-20 \mathrm{C}$ and used within 2 days. Tritium-labeled RNA was prepared by incorporation of uridine- $5{ }^{3} \mathrm{H}$ (specific activity greater than $20 \mathrm{Ci} / \mathrm{mm}$, New England Nuclear Corp.). The term "late" RNA refers to virus-specific RNA synthesized after the beginning of viral DNA replication; it was prepared from cells harvested at 18 to $19 \mathrm{hr}$ postinfection. "Early" RNA refers to virus-specific RNA synthesized before the initiation of viral DNA synthesis; it was extracted from cells harvested 6 to 7 $\mathrm{hr}$ after infection (unless noted otherwise). To ensure that only early RNA was made, $2 \mu \mathrm{M} 5$-fluorodeoxyuridine (FUdR; Hoffmann-LaRoche, Inc., Nutley, N.J.) was often added to the culture at the time of infection $(2,17)$ although this step was not essential.

Alkaline degradation of RNA. Controlled partial hydrolysis of RNA (6) was performed by adjusting the preparation to $1 \mathrm{~N} \mathrm{NaOH}$. After $90 \mathrm{sec}$ at 23 to $27 \mathrm{C}$, the solution was rapidly adjusted to $p \mathrm{H} \mathrm{7.0,}$ cooled in an ice bath, and dialyzed against 6 liters of $2 \times$ SSC.

Sedimentation analysis of RNA. For sucrose density gradient centrifugation, RNA (dissolved in $0.01 \mathrm{M}$ sodium acetate, $p \mathrm{H} 5.1$ ) was layered on a 5 to $20 \%$ $(\mathrm{w} / \mathrm{v})$ linear sucrose gradient containing $0.01 \mathrm{M}$ sodium acetate, $0.05 \mathrm{M} \mathrm{NaCl}$, and $100 \mu \mathrm{M} \mathrm{MgCl}_{2}$ at $p \mathrm{H} 5.1$ (47). The gradients were centrifuged at 63,581 $\times g$ for $6 \mathrm{hr}$ in the SW 25 rotor of a Spinco model $\mathrm{L}$ preparative centrifuge.

Isolation of polyribosomes and extraction of RNA. Polyribosomes from uninfected and infected KB cells were analyzed and isolated as described previously $(52,53)$. For isolation of RNA, fractions of the sucrose gradient were pooled and diluted with an equal volume of a solution containing $0.5 \%$ sodium dodecyl sulfate (SDS), $0.10 \mathrm{M} \mathrm{NaCl}, 0.01 \mathrm{M}$ tris(hydroxymethyl)aminomethane (Tris), $p \mathrm{H} 7.4$ (21, 24). The RNA was precipitated with ethanol, extensively dialyzed against $2 \times$ SSC, frozen at $-20 \mathrm{C}$, and used within 2 days.

DNA-RNA hybridization. Purified viral DNA was immobilized on nitrocellulose membrane filters (Schleicher and Schuell, type B6, $25 \mathrm{~mm}$ ), and hybridization was performed as described by Gillespie and Spiegelman (23). Hybridization was carried out at $65 \mathrm{C}$ for $18 \mathrm{hr}$ in $1 \mathrm{ml}$ of $2 \times$ SSC containing $0.1 \%$ SDS.

Three variations of the presaturation hybridizationinhibition technique were employed. (i) Method A (22). After the first hybridization reaction with increasing amounts of unlabeled, inhibiting RNA, filters were removed from their reaction vessels, rinsed twice in $400 \mathrm{ml}$ of $2 \times \mathrm{SSC}$, washed on each side with $50 \mathrm{ml}$ of the buffer by suction filtration and treated with pancreatic ribonuclease $(20 \mu \mathrm{g} / \mathrm{ml}$ at room temperature for $1 \mathrm{hr}$; ribonuclease was previously heated at $90 \mathrm{C}$ for $10 \mathrm{~min}$ to inactivate any contaminating deoxyribonuclease). After ribonuclease hydrolysis, filters were again rinsed twice in $400 \mathrm{ml}$ of buffer and washed by filtration. No residual ribonuclease activity was detected. The ${ }^{3} \mathrm{H}$-labeled RNA sample was then added for the second incubation. As determined from the thermal elution profile in $2 \times$ SSC, the DNA-RNA hybrid formed in the first reaction is a stable complex which will survive the second incubation at $65 \mathrm{C}$. After the second hybridization reaction, the filters were again subjected to the same washing and ribonuclease procedure. Each filter was then dried, placed in $5 \mathrm{ml}$ of a solution of $0.5 \mathrm{~g}$ of 1,4 -bis2-(5-phenyloxazolyl)-benzene and $6.0 \mathrm{~g}$ of 2,5 diphenyloxazole per liter of toluene, and counted in a Packard Tri-Carb liquid scintillation spectrometer.

(ii) Method B (48). After the first hybridization reaction, filters were removed from their reaction vessels and washed twice in $20 \mathrm{ml}$ of $2 \times \mathrm{SSC}$ at $65 \mathrm{C}$ for $45 \mathrm{~min}$. After the second incubation with labeled RNA, the extensive washing and ribonuclease treatment of method A were employed.

(iii) Method C (54). Subsequent to the first hybridization reaction, filters were removed from their reaction vessels and rinsed twice at room temperature in $2 \mathrm{ml}$ of $2 \times \mathrm{SSC}$. After the second incubation with labeled RNA, the extensive washing and ribonuclease treatment of method A were employed.

\section{RESULTS}

Hybridization of early and late virus-specific RNA species. Virus-specific RNA was found at 6 hr after infection in extracts of total RNA from cells infected in the presence of $2 \mu \mathrm{M}$ FUdR. The saturation of $2 \mu \mathrm{g}$ of adenovirus type 2 DNA with ${ }^{3} \mathrm{H}$-early RNA is shown in Fig. 1A. To achieve saturation with ${ }^{3} \mathrm{H}$-late RNA (i.e., $18 \mathrm{hr}$ after infection) required addition of much less nucleic acid (Fig. 1B). 


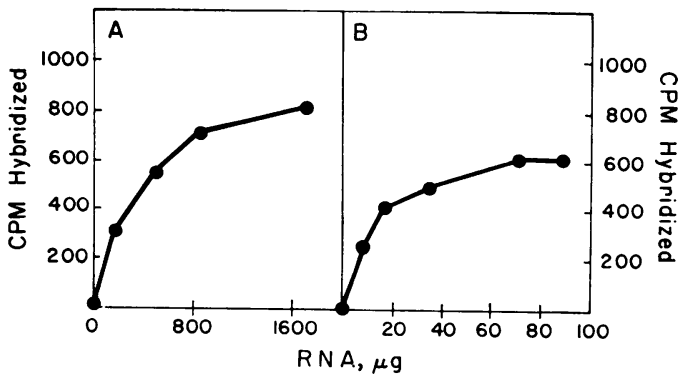

FIG. 1. Detection of early and late virus-specific RNA after infection with adenovirus type 2. Cells were infected at an input multiplicity of 100 fluorescent focus-forming units per cell. Various amounts of RNA (prepared from cells by phenol-SDS extraction) were incubated with filter-bound DNA for $18 \mathrm{hr}$ at $65 \mathrm{C}$ in $2 \times$ SSC containing $0.1 \%$ SDS. Radioactivity measured was that found in the ribonuclease-resistant hybrid. Hybridization of $2 \mu \mathrm{g}$ of purified type 2 adenovirus DNA was performed with $R N A$ labeled with 2 $\mu \mathrm{Ci}$ of ${ }^{3} \mathrm{H}$-uridine per $\mathrm{ml}$ from 6.0 to $6.5 \mathrm{hr}$ postinfection in the presence of $2 \mu \mathrm{M}$ FUdR added at the time of infection $(A)$ and with $R N A$ labeled with $1 \mu \mathrm{Ci} / \mathrm{ml}$ from 18.0 to $18.5 \mathrm{hr}$ postinfection $(B)$.

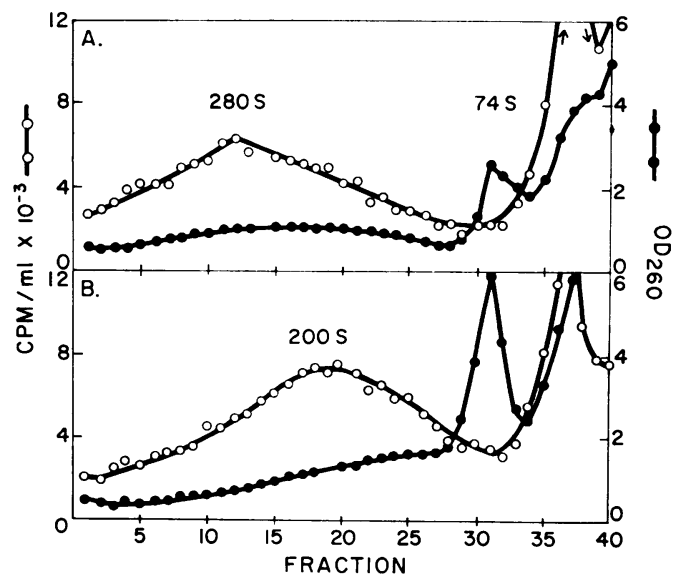

FIG. 2. Polyribosome profiles of uninfected $(A)$ and type 2 adenovirus-infected cells $(B)$. Cells infected with 100 fluorescent focus-forming units of type 2 adenovirus per cell were labeled with $2.0 \mu \mathrm{Ci}$ of ${ }^{14} \mathrm{C}$ amino acids per $\mathrm{ml}$ for $1 \mathrm{~min}$ at $18 \mathrm{hr}$ postinfection. Uninfected cells were similarly labeled at the same time. Cytoplasmic extracts were layered on 15 to $30 \%$ $(w / v)$ sucrose gradients and centrifuged for $90 \mathrm{~min}$ at $22,500 \mathrm{rev} / \mathrm{min}$ in a Spinco $S W 25$ rotor at $4 \mathrm{C}$. Symbols: (O) counts per minute per milliliter $\times 10^{-3}$; (O) optical density at $260 \mathrm{~nm}$.

To detect virus-specific RNA much earlier than $6 \mathrm{hr}$ after infection, experiments were devised to obtain RNA enriched with respect to viral cRNA species. Cytoplasmic extracts of in- fected cells were layered on 15 to $30 \%$ (w/v) sucrose density gradients and centrifuged. The RNA obtained from fractions in the polyribosome region of the gradient was used in the annealing reaction. The sedimentation analyses of uninfected and infected cells labeled for 1 min with ${ }^{14} \mathrm{C}$ amino acids $18 \mathrm{hr}$ after infection are shown in Fig. 2. By $18 \mathrm{hr}$ after infection, there was a marked shift in the size of the polyribosomes from a maximum of $280 S$ in uninfected cells to $200 S$ in the infected cells (52). Assuming that the early and late cRNA species are of similar sizes, in early stages of infection, fractions 14 to 26 might be expected to be richest in species of virus-specific RNA. Therefore, cells were labeled with ${ }^{3} \mathrm{H}$-uridine from 3 to $3.5 \mathrm{hr}$ after infection. The sucrose gradients were divided into three pools consisting of fractions 1 to 13 , fractions 14 to 26 , and fractions 27 to 40 . The hybridization reactions were performed with the RNA obtained from each pool (Fig. 3). With fractions from what would become the height of the polyribosome peak late in infection, i.e., fractions 14 to 26 (Fig. 3B), $1.5 \%$ of the radioactivity incorporated into these polyribosomes from 3 to $3.5 \mathrm{hr}$ after infection was

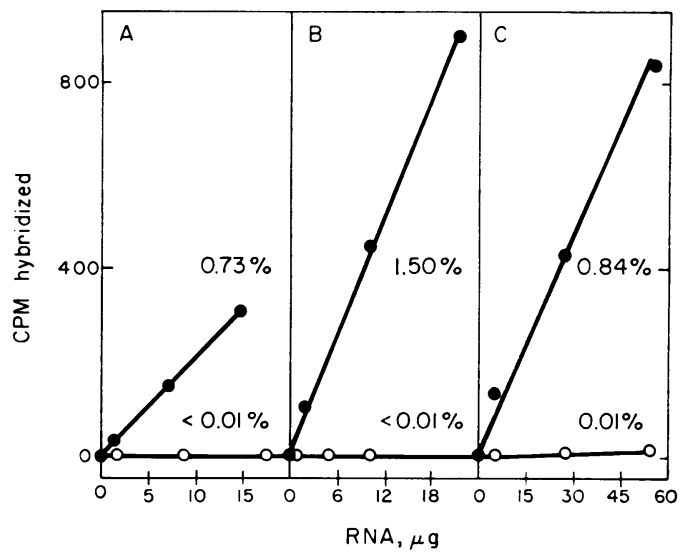

FIG. 3. Measurement of early virus-specific $R N A$ from polyribosomes of cells infected with type 2 adenovirus. Cells infected with 100 fluorescent focusforming units of virus per cell (O) and uninfected cells (O) were labeled from 3.0 to $3.5 \mathrm{hr}$ postinfection with $4.0 \mu \mathrm{Ci}$ of ${ }^{3} \mathrm{H}$-uridine per $\mathrm{ml}$. Cytoplasmic extracts were centrifuged as described in Fig. 2. Pooled fractions were treated with an equal volume of a solution containing $0.5 \%$ SDS, $0.10 \mathrm{M} \mathrm{NaCl}, 0.01$ y Tris (pH 7.4). $R N A$ was precipitated with ethanol, dialyzed against $2 \times S S C$, and used in hybridization with viral DNA as described in Fig. 1. A 2- $\mu$ g amount of type 2 adenovirus DNA was hybridized with increasing amounts of ${ }^{3} \mathrm{H}-\mathrm{RN} A$ from pool comprising fractions 1 to 13 from sucrose gradient $(A)$; pool comprising fractions 14 to 26 (B); pool comprising fractions 27 to $40(C)$. 


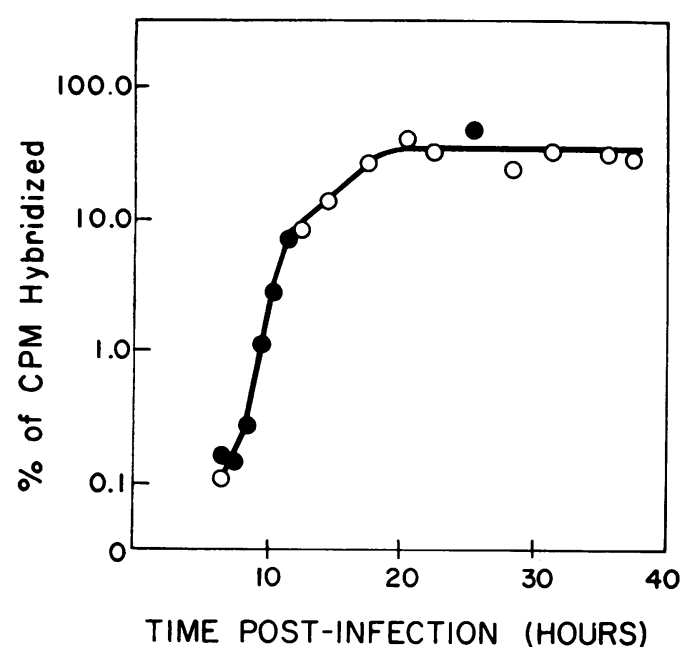

FIG. 4. Synthesis of virus-specific RNA at various times after infection. Cells were infected at an input multiplicity of 100 fluorescent focus-forming units per cell and were labeled with ${ }^{3} \mathrm{H}$-uridine $(2 \mu \mathrm{Ci} / \mathrm{ml}$ of culture) for 1-hr periods at various times after infection. RNA was prepared and hybridization performed as described in Fig. 1. DNA concentrations ranged from 2 to $10 \mu \mathrm{g} /$ filter. Counts per minute hybridized per filter for the 154 hybridization samples assayed ranged from 65 to 24,109 counts/min. The average value for nonspecific binding, determined by incubation of the 17 RNA samples with 79 blank filters, was 4 counts/min. Symbols (O) and (O) refer to two separate experiments. Per cent of counts per minute hybridized is the number of counts per minute hybridized at infinite DNA concentration (determined as described in text) divided by the number of counts per minute added to the hybridization reaction mixture, multiplied by 100 .

found in virus-specific RNA. Significant incorporation into viral species, 0.73 and $0.84 \%$ for fractions 1 to 13 (Fig. 3A) and fractions 27 to 40 (Fig. 3C), respectively, were found in other portions of the gradient. As a measurement of nonspecific binding, no more than $0.01 \%$ of the counts from corresponding fractions of labeled uninfected cells was found to bind to viral DNA on filters.

Rate of synthesis of virus-specified RNA. To measure the kinetics of transcription of the viral genome, RNA was extracted from cells labeled for 1-hr periods at various times after infection. A constant amount of each ${ }^{3} \mathrm{H}-\mathrm{RNA}$ sample was hybridized with four or five different concentrations of purified viral DNA, varying from 2 to 10 $\mu \mathrm{g}$ per filter. (As the per cent of viral RNA varied, the amount of DNA needed to saturate each ${ }^{3} \mathrm{H}$ RNA sample also varied. To perform the experiment with a single DNA concentration would entail the danger that the concentration chosen might not be saturating for all samples). From reciprocal plots constructed from each set of data (see Appendix, part I), the per cent of the incorporated ${ }^{3} \mathrm{H}$-uridine which was in virus-specific RNA was determined. These values plotted as a function of time after infection are shown in Fig. 4. The per cent of label incorporated into virusspecific RNA achieved a maximum value of about $40 \%$ at $20 \mathrm{hr}$ postinfection and then remained constant.

Analysis of early and late viral cRNA species by hybridization-inhibition. To determine whether species of early virus-specific RNA are transcribed or are present late in infection, and conversely whether so-called late species of RNA are present before replication of viral DNA, presaturation hybridization-inhibition analyses were performed by method A (see above). Experiments were done by using a constant amount of ${ }^{3} \mathrm{H}$-early RNA and increasing amounts of unlabeled RNA obtained during the late phases of infection (Fig. 5A). To calculate the per cent inhibition of hybridization at infinite concentrations of competing RNA species, the reciprocal plots shown in Fig. 5C and D were constructed. Graphical analysis (see Appendix, part II) shows that $75 \%$ of the label was incorporated into species of cRNA whose hybridization could not be inhibited by saturating amounts of unlabeled late cRNA (Fig. 5C). When the inhibition of hybridization of ${ }^{3} \mathrm{H}$-late cRNA by unlabeled early RNA was measured (Fig. 5B), 25\% inhibition was observed (Fig. 5D). Hybridization of the ${ }^{3} \mathrm{H}$-labeled RNA species was inhibited by homologous preparations: $100 \%$ inhibition with the late and $95 \%$ inhibition with the early RNA preparations (determined from plots shown in Fig. 5C and D). The specificity of the inhibition was indicated by the fact that uninfected KB cell RNA did not inhibit hybridization (Fig. 5B).

Evaluation of $h$ ybridization-inhibition techniques. The ability of unlabeled late viral RNA to inhibit the hybridization of ${ }^{3} \mathrm{H}$-early RNA was studied by using a number of techniques. Data obtained by method $\mathrm{A}$ are shown in Fig. 6A. The experiment was performed with two different nonsaturating concentrations of ${ }^{3} \mathrm{H}$-early RNA and also with a quantity of ${ }^{3} \mathrm{H}$-labeled RNA which approached saturation of the DNA. As shown earlier (Fig. 1A), very large quantities of early RNA were needed to saturate $2 \mu \mathrm{g}$ of viral DNA. Therefore, only $0.2 \mu \mathrm{g}$ of DNA was used in the third experiment. In all three cases, the results were very similar; that is, 60 to $70 \%$ of the ${ }^{3} \mathrm{H}$ uridine was incorporated into species of RNA whose hybridization was not inhibited by saturating amounts of unlabeled late RNA. 

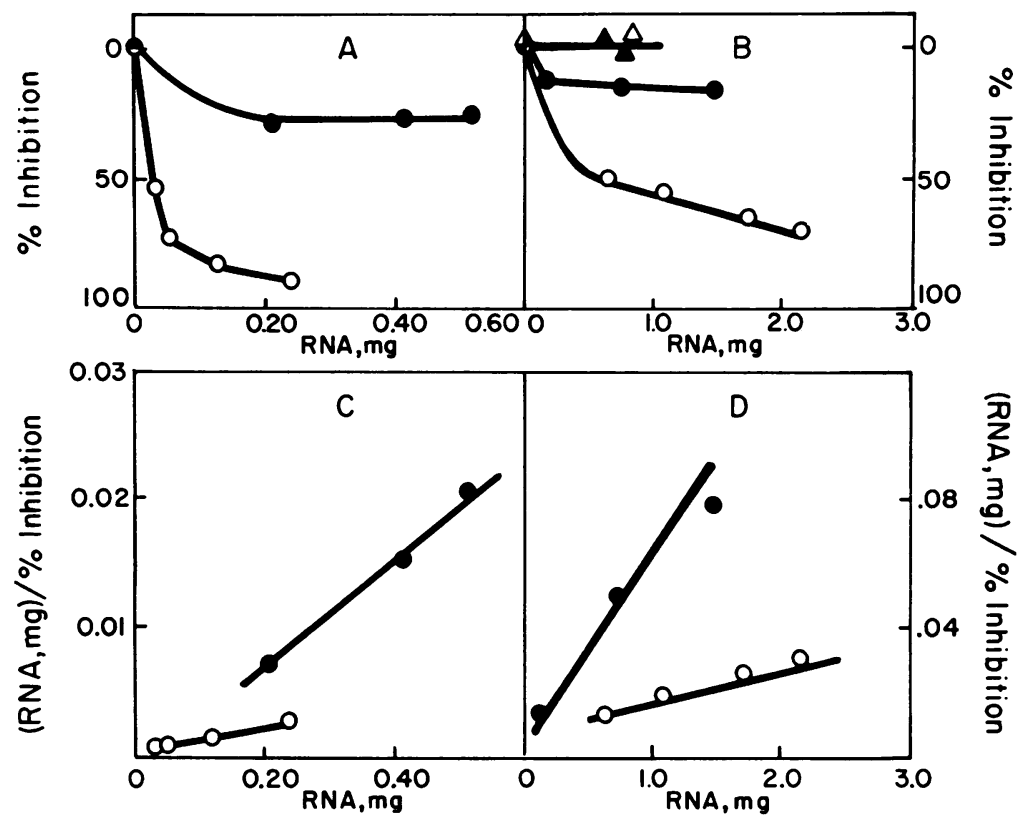

FIG. 5. Transcription of virus-specific RNA species early or late in infection with type 2 adenovirus as determined by hybridization-inhibition with heterologous or homologous RNA species. For these experiments, cells were infected and RNA was prepared as described in Fig. 1. Conditions for the hybridization reactions were those listed in Fig. 1. (A) Hybridization-inhibition of $(O)^{3} \mathrm{H}-\mathrm{RNA}$ labeled with $1.3 \mu \mathrm{Ci} / \mathrm{ml}$ from 6 to $7 \mathrm{hr}$ postinfection (i.e., early) in the presence of $2 \mu \mathrm{M}$ FUdR competed by unlabeled RNA extracted from cells harvested at $18 \mathrm{hr}$ postinfection (i.e., late). Filters were washed by method $A$ (that is, extensive washing and ribonuclease treatment after both hybridization reactions; see text for complete details). (O) ${ }^{3} \mathrm{H}-\mathrm{RNA}$ labeled with $2.0 \mu \mathrm{Ci} / \mathrm{ml}$ from 18.0 to $18.5 \mathrm{hr}$ postinfection competed by unlabeled $R N A$ from cells harvested at $18 \mathrm{hr}$ postinfection. Filters were washed by method $A$. (B) Hybridization-inhibition of $(O){ }^{3} \mathrm{H}-\mathrm{RN}$ A labeled with $1.0 \mu \mathrm{Ci} / \mathrm{ml}$ from 18.0 to $18.5 \mathrm{hr}$ postinfection competed by unlabeled RNA extracted from cells infected in the presence of FUdR and harvested at $6.5 \mathrm{hr}$ postinfection. Filters were washed by method $\mathrm{A}$. (O) ${ }^{3} \mathrm{H}-\mathrm{RNA}$ labeled with $1.0 \mu \mathrm{Ci} / \mathrm{ml}$ from 6.0 to $6.5 \mathrm{hr}$ postinfection by unlabeled RNA extracted from cells harvested at $6.5 \mathrm{hr}$ postinfection, both in the presence of 2 $\mu M$ FUdR. Filters were washed by method $\mathrm{A}$. (A) ${ }^{3} \mathrm{H}-\mathrm{RN}$ A labeled with $1.0 \mu \mathrm{Ci} / \mathrm{ml}$ from 18.0 to $18.5 \mathrm{hr}$ postinfection by unlabeled uninfected $K B$ cell $R N A$. Filters were washed by method $A .(\triangle){ }^{3} H-R N A$ labeled with 3.0 $\mu \mathrm{Ci} / \mathrm{ml}$ from 6 to $7 \mathrm{hr}$ postinfection in the presence of FUdR by unlabeled uninfected $K B$ cell $R N A$. Filters washed by method $B$ (that is, rinsing at $65 C$ after first hybridization reaction, extensive washing, and ribonuclease treatment after second reaction; see text for complete details). $(C)$ and $(D)$. Reciprocal plots (see text) of the data presented in Fig. $5 A$ and $5 B$, with symbols denoting the same experiments.

By using method B (Fig. 6B), it was found that unlabeled late RNA inhibited hybridization of about $50 \%$ of the ${ }^{3} \mathrm{H}$-early RNA. This method too yielded reproducible results at widely varying concentrations of labeled RNA. When the washing procedure used after hybridization with competing RNA was less extensive (method C), the results were more variable. Typical data are shown in Fig. 6C. Repeated performance of the experiment with this technique showed that unlabeled late RNA inhibited the hybridization of ${ }^{3} \mathrm{H}$-early RNA to an extent which varied from about $40 \%$ to greater than $98 \%$.

Since different preparations of unlabeled late RNA and ${ }^{3} \mathrm{H}$-early RNA (labeled either in the presence or absence of FUdR) gave reproducible results with methods $\mathrm{A}$ and $\mathrm{B}$, it was postulated that the variation was not due to the population of virus-specific RNA molecules in the preparations but rather that the variation was inherent in the technique (i.e., method C) employed.

These data suggested that the initial hybridization with competing RNA frequently resulted in areas of limited hybridization and residual loops and tails of RNA which, if not removed, could effectively but nonspecifically compete with subsequent hybridization of the labeled virus-specific RNA. The ribonuclease hydrolysis and extensive washing (method A) or rinsing at elevated temperature (method B) markedly reduced or eliminated this form of nonspecific competition. But the gentler rinsing technique employed in method C only partially and to a variable extent eliminated the nonspecific forms of hybridization. 

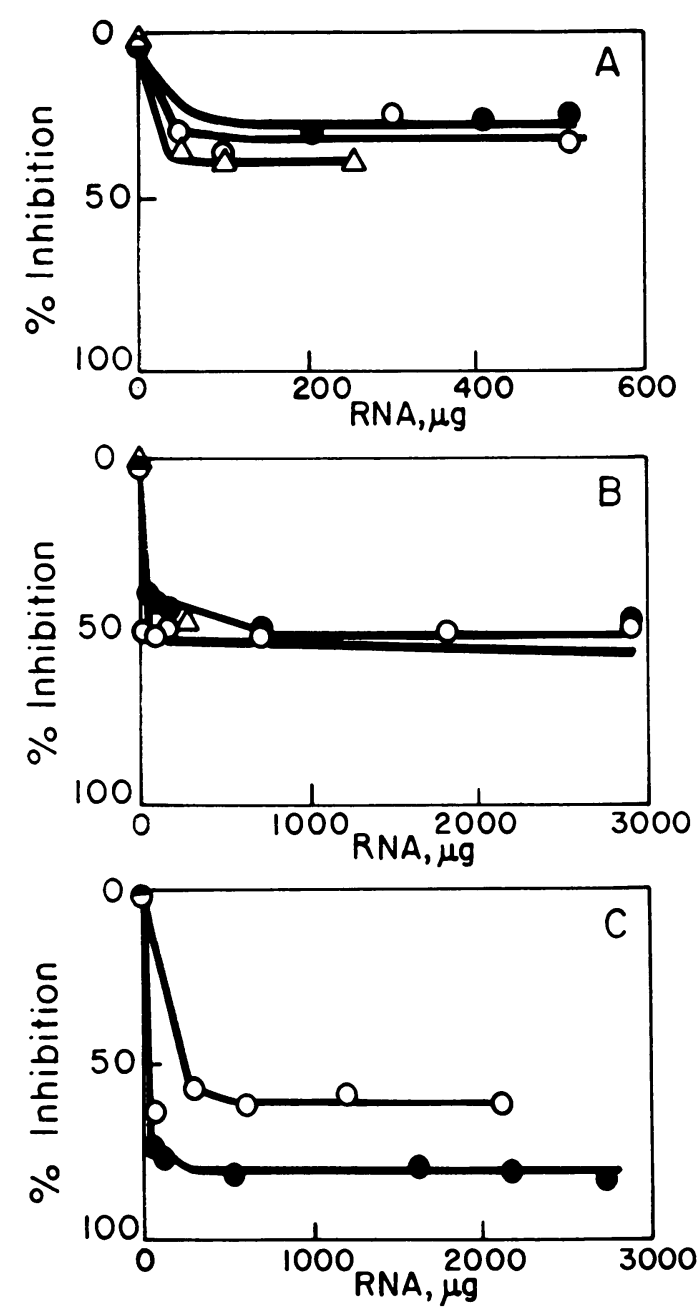

FIG. 6. Hybridization-inhibition of ${ }^{3} \mathrm{H}$-early $R N A$ by intact, unlabeled late RNA extracted from adenovirus-infected cells harvested at $18 \mathrm{hr}$ after infection with 100 fluorescent focus-forming units per cell of type 2 virus. RNA was prepared as described in Fig. 1. (A) Filters were washed by method $A$ (extensive washing and ribonuclease treatment after both hybridization reactions). Hybridization-inhibition was performed with various amounts of intact unlabeled late RNA and (O) $48.4 \mu \mathrm{g}$ of ${ }^{3} \mathrm{H}$-RNA labeled with $3.0 \mu \mathrm{Ci}$ of ${ }^{3} \mathrm{H}$-uridine per $\mathrm{ml}$ from 6.0 to $6.5 \mathrm{hr}$ postinfection, $2 \mu \mathrm{g}$ of $\mathrm{DNA} /$ filter; (O) $116.1 \mu \mathrm{g}$ of ${ }^{3} \mathrm{H}$-RNA labeled with $1.3 \mu \mathrm{Ci} / \mathrm{ml}$ from 6 to $7 \mathrm{hr}$ postinfection in the presence of $2 \mu \mathrm{M}$ FUdR, $2 \mu \mathrm{g}$ of DNA/filter; $(\triangle) 406.7 \mu \mathrm{g}$ of ${ }^{3} \mathrm{H}-\mathrm{RNA}$ labeled with $3.0 \mu \mathrm{Ci} / \mathrm{ml}$ from 3 to $7 \mathrm{hr}$ postinfection in the presence of FUdR, $0.2 \mu \mathrm{g}$ of $\mathrm{DNA}$ /filter. (B) Filters were washed by method $B$ (rinsing at $65 C$ after first hybridization reaction; extensive washing and ribonuclease treatment after second reaction). Hybridization-inhibition was performed with various amounts of intact unlabeled late RNA and (O) $22.4 \mu \mathrm{g}$ of ${ }^{3} \mathrm{H}-\mathrm{RNA}$ labeled with $3.0 \mu \mathrm{Ci} / \mathrm{ml}$ from 6 to $7 \mathrm{hr}$ postinfection,

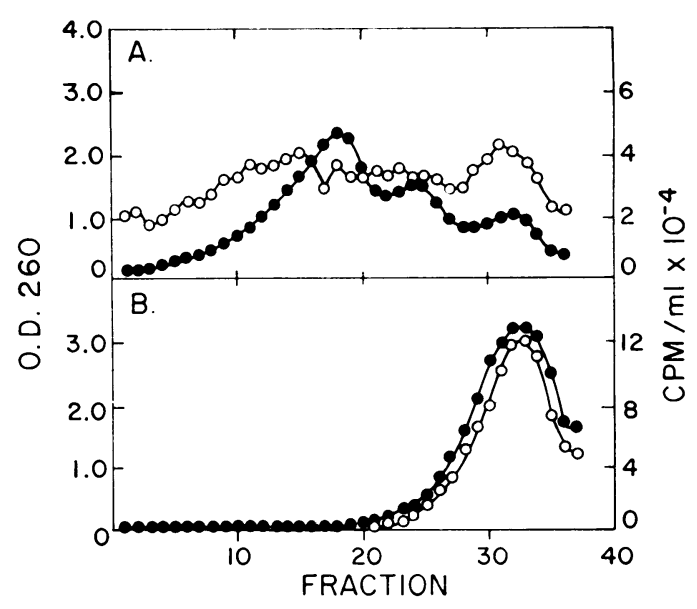

FIG. 7. Rate zonal sedimentation in sucrose gradients $\left(5\right.$ to $20 \%$ ) of intact and alkaline-degraded ${ }^{3} \mathrm{H}$ late $R N A$ from type 2 adenovirus-infected $K B$ cells $19 \mathrm{hr}$ after infection. Cells were infected and RNA was prepared as described in Fig. 1. Partial alkaline degradation was accomplished by treating $R N A$ with $1 \mathrm{~N}$ $\mathrm{NaOH}$ for $90 \mathrm{sec}$ at $23 \mathrm{C}$. RNA was dissolved in 0.01 $\mathrm{NaAc}(\mathrm{pH} \mathrm{5.1)}$ and layered on a gradient containing 0.01 . N NaAc, 0.05 M NaCl, and $100 \mu \mathrm{M} \mathrm{MgCl}$ (pH 5.1). Centrifugation was at 25,000 rev/min for $6 \mathrm{hr}$ in a Spinco $S W 25$ rotor. $(A){ }^{3} \mathrm{H}$-late $R N A$ labeled with $1.0 \mu \mathrm{Ci}$ of ${ }^{3} \mathrm{H}$-uridine per $\mathrm{ml}$ from 18 to $19 \mathrm{hr}$ postinfection. (B) Same preparation after controlled alkaline degradation. Optical density at $260 \mathrm{~nm}(\mathbf{O})$. Counts per minute per milliliter $\times 10^{-4}(\mathrm{O})$.

If this model were correct, it should be possible to obtain relatively similar results with any of the three methods studied when the competing RNA is sufficiently small so that tails and loops cannot develop. Therefore, to test the proposed model of nonspecific competition, the experiments were repeated by using alkaline-degraded, unlabeled late RNA (see above) as the inhibiting RNA. For

$2 \mu \mathrm{g}$ of $\mathrm{DNA} /$ filter; $46.3 \mu \mathrm{g}$ of ${ }^{3} \mathrm{H}-\mathrm{RN} \boldsymbol{A}$ labeled with $3.0 \mu \mathrm{Ci} / \mathrm{ml}$ from 6 to $7 \mathrm{hr}$ postinfection in the presence of FUdR, $2 \mu \mathrm{g}$ of $\mathrm{DNA} /$ filter; $(\triangle) 406.7$ $\mu \mathrm{g}$ of ${ }^{3} \mathrm{H}$-RNA labeled with $3.0 \mu \mathrm{Ci} / \mathrm{ml}$ from 3 to 7 hr postinfection in the presence of FUdR, $0.2 \mu \mathrm{g}$ of DNA/filter. $(C)$ Filters were washed by method $C$ (mild rinsing at room temperature after first hybridization reaction; extensive washing and ribonuclease treatment after the second reaction). Hybridizationinhibition was performed with various amounts of intact unlabeled late RNA and (O) $45.2 \mu \mathrm{g}$ of ${ }^{3} \mathrm{H}-\mathrm{RNA}$ labeled with $3.0 \mu \mathrm{Ci} / \mathrm{ml}$ from 6 to $7 \mathrm{hr}$ postinfection in the presence of FUdR, $2 \mu \mathrm{g}$ of $\mathrm{DNA} /$ filter; (O) $84.0 \mu \mathrm{g}$ of ${ }^{3} \mathrm{H}-\mathrm{RNA}$ labeled with $4.0 \mu \mathrm{Ci} / \mathrm{ml}$ from 6 to $7 \mathrm{hr}$ postinfection, $2 \mu \mathrm{g}$ of $\mathrm{DNA} /$ filter. Refer to text for complete details of the three washing procedures. 
these experiments, it was essential that the degraded RNA be of sufficient size to form a ribonuclease-resistant hybrid to the same extent and with the same specificity as the intact RNA but still be sufficiently small to eliminate the possibility of loop or tail formation. The sedimentation analysis of a preparation of ${ }^{3} \mathrm{H}$-late RNA before and after limited alkaline degradation is shown in Fig. 7. Before degradation, the RNA exhibited a great heterogeneity of size; after alkaline treatment, the RNA sedimented in a single peak with a sedimentation coefficient of about $4 S$. The hybridization characteristics of the intact and degraded preparations were compared in the following way: DNA saturation curves were made by using $2 \mu \mathrm{g}$ of viral DNA and increasing amounts of each ${ }^{3} \mathrm{H}-\mathrm{RNA}$ preparation. The plots shown in Fig. 8 were then constructed. The appropriate calculations (see Appendix, part III) show that the counts per minute hybridized at saturation were 2,268 and 2,222 for the intact and degraded RNA species, respectively. The quantities of RNA giving half saturation were $10.5 \mu \mathrm{g}$ for intact and $8.2 \mu \mathrm{g}$ for degraded RNA.

When hybridization-inhibition studies were made with alkaline-degraded RNA, all three

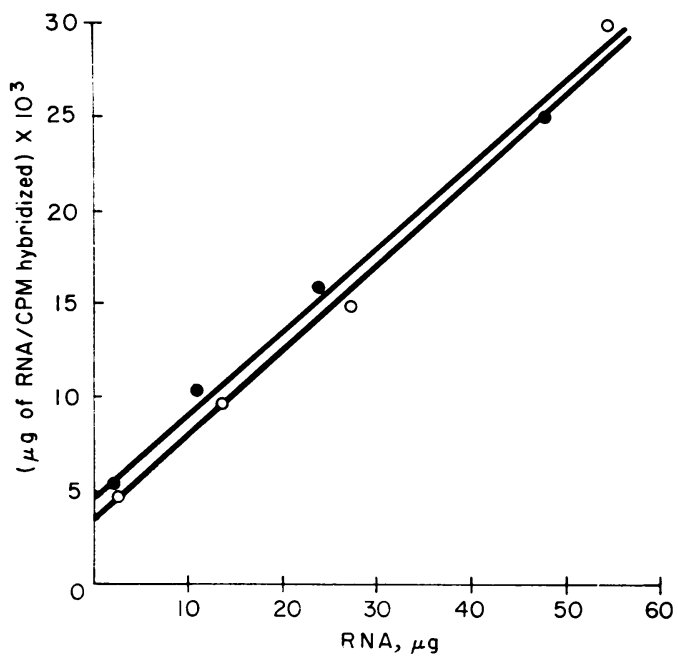

FIG. 8. Hybridization characteristics of intact ${ }^{3} \mathrm{H}$ late $R N A(O)$ and alkaline-degraded ${ }^{3} \mathrm{H}$-late $R N A$ (O). Cells were infected with 100 fluorescent focusforming units per cell. RNA was labeled with $2.0 \mu \mathrm{Ci} / \mathrm{ml}$ from 18 to $19 \mathrm{hr}$ postinfection and was ex!racted as described in Fig. 1. Partial alkaline degradation was accomplished as dercribed in Fig. 7. Hybridization with 2 $\mu \mathrm{g}$ of $\mathrm{DNA} /$ filter was performed with various amounts of intact and degraded RNA species (average specific activity: 1,194 counts per min per $\mu \mathrm{g}$ ) using the condifions listed in Fig. 1. The theoretical basis for the reciprocal plots is described in the Appendix, part III.

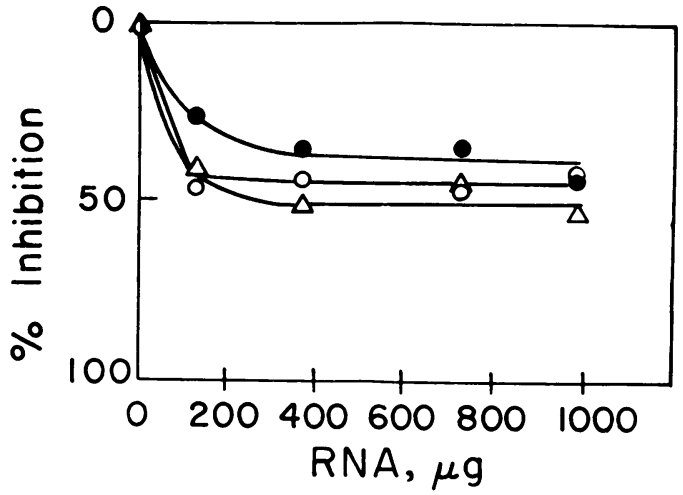

FIG. 9. Hybridization-inhibition of ${ }^{3} \mathrm{H}$-early $R N A$ by alkaline-degraded unlabeled $R N A$ extracted from adenovirus-infected cells harvested at $18 \mathrm{hr}$ after infection with 100 fluorescent focus-forming units per cell. RNA was prepared as described in Fig. 1. Partial alkaline-degradation was achieved by treating the $R N A$ with $1 \mathrm{~N} \mathrm{NaOH}$ for $90 \mathrm{sec}$ (see Fig. 7). Conditions for the hybridization reactions are listed in Fig. 1. Hybridization-inhibition was performed with $104.5 \mu \mathrm{g}$ of ${ }^{3} \mathrm{H}$-early $R N A$ labeled with $2.25 \mu \mathrm{Ci}$ of ${ }^{3} \mathrm{H}$-uridine per $\mathrm{ml}$ from 6 to $7 \mathrm{hr}$ postinfection in the presence of $2 \mu \mathrm{M} F \mathrm{WdR}$ and various amounts of alkaline-degraded unlabeled late $R N A ; 2 \mu \mathrm{g}$ of $\mathrm{DNA} /$ filter. Filters were washed by method $A(O)$, method $B(O)$, and method $C$ $(\triangle)$. Refer to Fig. 6 and text for complete details of the three washing procedures.

methods gave approximately the same result (Fig. 9): saturating amounts of unlabeled late RNA inhibited the hybridization of $35 \%$ (method A) to $50 \%$ (method C) of the ${ }^{3} \mathrm{H}$-early viral RNA.

The efficacy of each of the three washing procedures was ascertained in the following way. Either intact or degraded ${ }^{3} \mathrm{H}$-late RNA was hybridized with adenovirus DNA, and the filters were then washed by the three methods (Table I). As expected, a closer correspondence was seen among the results with the three different techniques when alkaline-degraded RNA rather than intact nucleic acid was used. It is noteworthy that method C, employing intact RNA, yielded the most variable results. Moreover, with either intact or degraded RNA, method A showed very little variation either within or among the three experiments (less than $5 \%$ by calculation of standard deviation).

\section{DISCUSSION}

In KB cells infected with type 2 adenovirus, the infecting viral DNA appears in the nucleus by $2 \mathrm{hr}$ after infection (37). However, $6 \mathrm{hr}$ postinfection is the earliest time newly transcribed viral RNA can be detected in the total RNA extracted. Thomas and Green (50) found that at $6 \mathrm{hr}$ about 
TABLE 1. Comparison of DNA-RNA hybridization techniques with intact and alkaline-degraded ${ }^{3} \mathrm{H}$-late $\mathrm{RNA}$ and type 2 adenovirus DNA

\begin{tabular}{|c|c|c|c|c|c|c|}
\hline \multirow{3}{*}{ Expt } & \multicolumn{6}{|c|}{ RNA hybridized (counts per min per filter) ${ }^{a}$} \\
\hline & \multicolumn{3}{|c|}{$\begin{array}{l}\text { Intact RNA } \\
\text { with method }\end{array}$} & \multicolumn{3}{|c|}{$\begin{array}{c}\text { Alkaline-degraded } \mathrm{RNA}^{b} \\
\text { with method }\end{array}$} \\
\hline & A & B & $\mathrm{C}$ & A & B & $\mathrm{C}$ \\
\hline \multirow[t]{4}{*}{1} & 100 & 211 & 315 & & & \\
\hline & 100 & 223 & 339 & & & \\
\hline & 100 & 199 & 291 & & & \\
\hline & 100 & 215 & 297 & & & \\
\hline \multirow[t]{3}{*}{2} & 100 & 182 & 132 & 100 & 135 & 146 \\
\hline & 100 & 186 & 126 & 100 & 131 & 144 \\
\hline & 100 & 176 & 183 & 100 & $\begin{array}{l}146 \\
138\end{array}$ & \\
\hline \multirow[t]{3}{*}{3} & 100 & 165 & 184 & 100 & 139 & 181 \\
\hline & 100 & 169 & 186 & 100 & 144 & 165 \\
\hline & 100 & 149 & 183 & 100 & 137 & 165 \\
\hline Avg & 100 & 187 & 224 & 100 & 139 & 160 \\
\hline
\end{tabular}

${ }^{a}$ Results are from a number of experiments performed with various concentrations of both RNA and DNA. So that the data from the three experiments could be compared, all data were normalized to 100 counts/min for results with method $A$. Filters treated by method $A$, with both intact and degraded RNA, showed very little variation among the experiments (less than $5 \%$ by calculation of standard deviation).

$b$ Partial alkaline degradation was accomplished by treating RNA with $1 \mathrm{~N} \mathrm{NaOH}$ for $90 \mathrm{sec}$ at $23 \mathrm{C}$.

${ }^{c}$ Filters were washed by the three methods described in the text.

$1.5 \%$ of the ${ }^{3} \mathrm{H}$-uridine incorporated into polyribosomes is in virus-specific hybridizable material. By using highly labeled material isolated from polyribosome fractions, to increase the ratio of viral to host RNA species, synthesis of virusdirected RNA can in fact be detected $3 \mathrm{hr}$ after infection (Fig. 3). Since viral DNA replication in type 2 adenovirus-infected KB cells begins about $7 \mathrm{hr}$ after infection $(25,27)$, this hybridizable material may be called early cRNA according to the classical definition developed from transcription studies with $\mathrm{T}$-even bacteriophages $(13,26)$. Moreover, the synthesis of virus-specific RNA may be detected in the presence of 5-fluorodeoxyuridine, an effective inhibitor (about 97\%) of adenovirus DNA synthesis $(2,17)$.

In studies of the transcription of type 5 adenovirus DNA in infected KB cells, Bello and Ginsberg (2) were unable to establish directly the existence of early viral RNA. In their work, DNARNA hybridization was performed with the total RNA extracted from infected cells by the tech- nique of Nygaard and Hall (41). Since virus-directed protein synthesis can be detected before the replication of viral DNA (45), it was suggested that early RNA may be synthesized at a level which made it difficult to detect by the methods used. It is shown here (Fig. 4) that in adenovirus type 2 infection, only 0.1 to $0.2 \%$ of the ${ }^{3} \mathrm{H}$-uridine incorporated into total RNA during an early time is in virus-specific material; by $20 \mathrm{hr}$ after infection, some $40 \%$ of incorporated ${ }^{3} \mathrm{H}$-uridine is in viral RNA. A great disparity between the amounts of early and late viral cRNA is also indicated by the experiments of Thomas and Green (50).

Transcription of early and late viral RNA species were compared by the technique of DNARNA hybridization-inhibition. Results were found to be dependent upon the experimental technique employed. In agreement with Darnell and associates $(3,14,48)$, significant differences in the results given by simultaneous and sequential hybridization-competition were observed (J. Lucas and H. S. Ginsberg, unpublished data). In addition, major differences were also detected with the various techniques of presaturation hybridization-inhibition which are commonly used $(22,48,54)$. It is important to note that all of the techniques employed are apparently specific in that uninfected KB cell RNA does not inhibit the hybridization of virus-specific RNA (Fig. 5B, references 51, 54). However, on the basis of the experiments with alkaline-degraded RNA, and on the assessment of the reproducibility of the various methods, it is concluded that when using intact RNA the procedure described by Gillespie (22), method A, is the technique of choice.

Early and late RNA species were therefore characterized by using hybridization-inhibition method A. Late RNA inhibited the hybridization of ${ }^{3} \mathrm{H}$-early RNA about $30 \%$ (Fig. 6A). Hence, 60 to $70 \%$ of the cRNA species synthesized before viral DNA replication are not synthesized (nor are they present) at late times in infection. To simplify further discussion, RNA which is transcribed prior to viral DNA replication, but not during the synthesis of late viral products, will be called early cRNA class I. (Our preliminary results indicate that early RNA species of class I are no longer present by $14 \mathrm{hr}$ after infection and are probably decreased in concentration as early as $9 \mathrm{hr}$.) The RNA species transcribed prior to viral DNA replication as well as late in infection will be called early cRNA class II.

About $75 \%$ of the label incorporated into late viral RNA is found in species whose hybridization cannot be inhibited by early RNA (Fig. 5B). This experiment defines that class of RNA whose 
synthesis begins only after the initiation of viral DNA synthesis, that is, true late cRNA. [Unpublished data (J. Lucas and H. S. Ginsberg) suggest that all species of RNA present late in the productive type 2 adenovirus infection of KB cells are also made in the abortive infection which the virus initiates in African green monkey kidney cells.] Conversely, the experiment indicates that about $25 \%$ of the labeled material is in cRNA species which are present at both early and late times.

At $18 \mathrm{hr}$ postinfection, the time at which the late RNA was prepared, about $30 \%$ of the label incorporated into total RNA is in viral species (Fig. 4). Therefore, at late times in infection, about $7.5 \%$ of the label incorporated into RNA enters species of early viral cRNA class II.

The per cent of incorporated label which enters early cRNA class II at $6 \mathrm{hr}$ after infection can also be calculated. At $6 \mathrm{hr}$, only about 0.1 to $0.2 \%$ of incorporated label is in viral RNA (Fig. 4). Moreover, the hybridization-inhibition experiment with unlabeled late and ${ }^{3} \mathrm{H}$-early RNA species (Fig. 6A) shows that about $30 \%$ of the label incorporated into viral cRNA at $6 \mathrm{hr}$ enters early cRNA class II. Therefore, some 0.03 to $0.06 \%$ of the label incorporated into total RNA at early times in infection enters early cRNA class II. Taking into account the observation that there is a 30 to $40 \%$ decrease in the incorporation of ${ }^{3} \mathrm{H}$ uridine into total RNA by $18 \mathrm{hr}$ after adenovirus infection $(2,44)$, it is found that the incorporation of label into class II early cRNA is enhanced (from 75- to 175-fold) after the initiation of viral DNA synthesis. [Let $x$ be the amount of ${ }^{3} \mathrm{H}$-uridine incorporated into total RNA at $18 \mathrm{hr}$ postinfection and $x_{1}$ the amount at $6 \mathrm{hr}$. The incorporation into early cRNA class II at $18 \mathrm{hr}$ is $0.075 x$, whereas that at $6 \mathrm{hr}$ is $0.0006 x_{1}$. Since $x$ is equal to about $0.6 x_{1}$, the ratio of incorporation into early cRNA class II at the two times is given by: (early cRNA class II at $18 \mathrm{hr}$ )/(early cRNA class II at $6 \mathrm{hr})=(0.075 x) /\left(0.0006 x_{1}\right)=\left(0.045 x_{1}\right) /$ $\left(0.0006 x_{1}\right)=75$. This calculation yields a minimal estimate of the ratio.] This enhanced incorporation could be due to (i) an increased rate of synthesis of early cRNA class II late in infection, (ii) a change in the pool size of the RNA precursor, or (iii) a great increase in the turnover rate of viral RNA late in infection. It would seem unlikely that changes in the latter two factors could account for an enhancement of such magnitude. [For example, it has been shown (44) that the amount of ${ }^{3} \mathrm{H}$-uridine incorporated into the acidsoluble fraction of type 2 adenovirus-infected KB cells is only about 1.5 times greater at $18 \mathrm{hr}$ than it is at $6 \mathrm{hr}$ after infection.] It is therefore suggested that the observation at least partially re- flects a greatly enhanced rate of synthesis of class II early cRNA late in infection. The observed enhancement also makes it unlikely that the continued synthesis of class II early RNA is simply due to transcription from partially uncoated virions which are not participating in the infection.

Experiments to distinguish the two classes of early cRNA temporally, for example, by performing hybridization-inhibition experiments with unlabeled $3 \mathrm{hr}$ and labeled $6 \mathrm{hr}$ RNA species, have been hampered by the difficulty of obtaining the large amounts of inhibiting RNA which would be needed to saturate the hybridizable DNA. As noted in earlier studies (2), early adenovirusspecified RNA is synthesized at an extremely low level.

The finding that some early cRNA species are not present at late times after type 2 adenovirus infection agrees with the data of Matsukage and Minagawa (39) suggesting that the synthesis of some early messenger RNA stopped late in T2infected Escherichia coli and with reports (19, 20) that in SPO1-infected Bacillus subtilis the concentration of early virus-directed messenger RNA is very much reduced after the initiation of viral DNA synthesis. Moreover, a recent study of T4 infection (46) has shown that there is a class of phage-specific RNA that is transcribed early but decreases late after infection ("true early") and a class ("quasi late") that is synthesized early but whose synthesis increases at late times $(8-10)$. These findings differ from previous results of Green and colleagues with adenovirus $(27,51)$ and with other hybridization analyses of the transcription of the DNA of vaccinia virus (43), simian virus $40(11,42)$, polyoma virus (34), and the bacteriophages T2 $(29,30)$ and T4 (7), which implied that all or nearly all early RNA species may be present during the transcription of late messenger RNA species. The comparison of hybridization techniques described in this paper suggests the possibility that some of the differences observed with the various viruses analyzed may be due to the techniques used rather than to basic differences in transcriptional control mechanisms, and perhaps the comparison indicates the need for a reevaluation of data in terms of the technical aspects of the hybridization methods employed.

\section{ACKNOWLEDGMENTS}

This investigation was supported by Public Health Service research grants AI-03620 and 5 TI-AI-203 from the National Institute of Allergy and Infectious Diseases. Joseph Lucas was supported by National Defense Education Act Title IV Fellowship 66-04895 and a National Science Foundation Traineeship.

We are most grateful to Joseph Higgs for his excellent assistance. 


\section{APPENDIX}

\section{Quantitative Analysis of Data from Hybridization Experiments}

Despite the complexity of the reactions involved, DNA and RNA saturation and hybridization-competition curves have been often observed to approximate rectangular hyperbolas. The experimental data obtained with adenovirus DNA and RNA fit this mathematical function. Discussions of the theory and application of quantitative analyses of hybridization experiments can be found in references $1,4,5,32,35$, 40,49 . The following treatment has been employed in analyzing the results presented in this paper.

I. Saturation of RNA with DNA. A plot of counts per minute (CPM) of ${ }^{3} \mathrm{H}-\mathrm{RNA}$ hybridized versus micrograms of DNA per filter approximates a rectangular hyperbola with the equation:

$$
\mathrm{CPM}_{\mathrm{h}}=\left(\mathrm{CPM}_{\mathrm{s}}\right) \stackrel{(\text { micrograms of DNA }) /}{\left(K_{1}+\text { micrograms of DNA }\right) .}
$$

Where $\mathrm{CPM}_{\mathrm{h}}=\mathrm{CPM}$ of ${ }^{3} \mathrm{H}-\mathrm{R} N \mathrm{~A}$ hybridized, $\mathrm{CPM}_{\mathrm{s}}=\mathrm{CPM}$ of ${ }^{3} \mathrm{H}-\mathrm{RNA}$ hybridized at saturating amounts of DNA, micrograms of DNA = quantity of DNA immobilized on a filter, $K_{1}=$ a constant.

Rearrangement of (1) yields:

Micrograms of DNA/CPM $=\left(1 / \mathrm{CPM}_{\mathrm{s}}\right)($ micrograms of DNA $)$

$$
+K_{1} / \mathrm{CPM}_{\mathrm{s}}
$$

Micrograms of DNA/CPM $h$ versus micrograms of DNA gives a straight line with a slope equal to $1 / \mathrm{CPM}_{\mathrm{B}}$. The reciprocal of the slope, when divided by the number of CPM of input RNA and multiplied by $100 \%$ gives the per cent of the ${ }^{3} \mathrm{H}$-uridine incorporated into total RNA which was found in the virus-specific species.

The $y$-intercept is equal to $K_{1} / \mathrm{CPM}_{\mathrm{s}}$, where $K_{1}$ is the micrograms of DNA per filter needed to attain one-half saturation of the RNA sample, as shown by the following.

Solving (2) for $K_{1}$ :

$$
\begin{aligned}
K_{1}=[(\text { micrograms of DNA) } & \left.\left(\mathrm{CPM}_{\mathrm{s}}\right) / \mathrm{CPM}_{\mathrm{h}}\right] \\
& - \text { micrograms of DNA }
\end{aligned}
$$

At one-half saturation of the RNA,

$$
\text { Micrograms of DNA = micrograms of } \mathrm{DNA}_{\mathrm{S} / 2}
$$

micrograms of $\mathrm{DNA}_{\mathbf{S} / 2}$ is the quantity of DNA per filter required to attain one-half saturation of the RNA, and

$$
\mathrm{CPM}_{\mathrm{h}}=\mathrm{CPM}_{\mathrm{s}} / 2
$$

Substituting (4) and (5) into equation (3) yields: $K_{1}=$

$$
\begin{array}{r}
{\left[\left(\text { micrograms of } \mathrm{DNA}_{\mathrm{s} / 2}\right)\left(\mathrm{CPM}_{\mathrm{s}}\right) /\left(\mathrm{CPM}_{\mathrm{s}} / 2\right)\right]} \\
- \text { micrograms of } \mathrm{DNA}_{\mathbf{S} / 2} \\
=\text { micrograms of } \mathrm{DNA}_{\mathrm{s} / 2}
\end{array}
$$

II. Hybridization-inhibition. A plot of per cent inhibition versus milligrams of competing RNA approximates a rectangular hyperbola with the equation:
$I_{0}=\left[\left(I_{\mathrm{s}}\right)\right.$ (milligrams of RNA) $] /$

$$
\left(K_{3}+\right.\text { milligrams of RNA) }
$$

Where $I_{0}=$ the observed inhibition, expressed as a per cent; $I_{s}=$ the per cent inhibition at saturating amounts of RNA; milligrams of RNA = quantity of input RNA (in milligrams); $K_{8}=a$ constant (equal to the milligrams of RNA input needed to attain one-half the maximal inhibition).

Rearrangement yields:

Milligrams of RNA $/ I_{0}$

$$
=\left(1 / I_{\mathrm{s}}\right) \text { (milligrams of RNA) }+K_{3} / I_{\mathrm{s}}
$$

Thus a plot of milligrams of RNA $I_{0}$ versus milligrams of RNA gives a straight line with a slope equal to $1 / I_{\mathrm{s}}$. The reciprocal of this yields the per cent inhibition obtained at infinite concentration of input RNA.

III. Saturation of DNA with RNA. A plot of CPM of ${ }^{3} \mathrm{H}-\mathrm{RNA}$ hybridized versus micrograms of RNA input approximates a rectangular hyperbola with the equation:

$$
\mathrm{CPM}_{\mathrm{h}}=\left[\left(\mathrm{CPM}_{\mathrm{s}}\right) \stackrel{(\mu \mathrm{g} \mathrm{RNA})] /}{\left(K_{2}+\text { micrograms of RNA }\right)}\right.
$$

Where $\mathrm{CPM}_{\mathrm{h}}=\mathrm{CPM}$ of ${ }^{3} \mathrm{H}$-RNA hybridized, $\mathrm{CPM}_{\mathbf{s}}=\mathrm{CPM}$ of ${ }^{3} \mathrm{H}-\mathrm{RNA}$ hybridized at saturating amounts of RNA, micrograms of RNA = quantity of input RNA (in micrograms), $K_{2}=$ a constant.

Rearrangement of (1) yields:

Micrograms of RNA/CPM

$$
\begin{aligned}
=\left(1 / \mathrm{CPM}_{\mathrm{s}}\right) \text { (micrograms of } & \mathrm{RNA}) \\
& +K_{2} / \mathrm{CPM}_{\mathrm{s}}
\end{aligned}
$$

A plot of micrograms of RNA/CPM ${ }_{h}$ versus micrograms of RNA gives a straight line with a slope equal to $1 / \mathrm{CPM}_{\mathrm{s}}$. The $\mathrm{Y}$-intercept is equal to $K_{2} / \mathrm{CPM}_{\mathrm{s}}$. The constant $K_{2}$ is equal to the micrograms of RNA input needed to attain one-half saturation of the DNA, as shown by the following equations.

Solving (2) for $K_{2}$ :

$K_{2}=\left[\left(\right.\right.$ micrograms of RNA) $\left.\left(\mathrm{CPM}_{\mathrm{s}}\right), \mathrm{CPM}_{\mathrm{h}}\right]$

- micrograms of RNA

At one-half saturation of the DNA,

Micrograms of RNA = micrograms of $\mathrm{RNA}_{S / 2}$

where micrograms of $\mathrm{RNA}_{\mathrm{S} / 2}$ is the micrograms of RNA input required to attain one-half saturation of the DNA, and

$$
\mathrm{CPM}_{\mathrm{h}}=\mathrm{CPM}_{\mathrm{s}} / 2
$$

Substituting (4) and (5) into equation (3) yields: $K_{2}=$

[(micrograms of $\left.\left.\mathrm{RNA}_{\mathrm{s} / 2}\right)\left(\mathrm{CPM}_{\mathrm{s}}\right) /\left(\mathrm{CPM}_{\mathrm{s}} / 2\right)\right]$

$$
\text { - micrograms of RNA } \text { ? }
$$

$$
=\text { micrograms of } \mathbf{R N A}_{\mathrm{S}}
$$

\section{LITERATURE CITED}

1. Avery, R. J., and J. E. M. Midgley. 1969. A new approach to the analysis of hybridization of bacterial nucleic acids. 
Analysis of the ribosomal ribonucleic acids of Bacillus subtilis. Biochem. J. 115:383-394.

2. Bello, L. J., and H. S. Ginsberg. 1969. Relationship between deoxyribonucleic acid-like ribonucleic acid synthesis and inhibition of host protein synthesis in type 5 adenovirusinfected KB cells. J. Virol. 3:106-113.

3. Birnboim, H. C., J. J. Pene, and J. E. Darnell. 1967. Studies on Hela cell nuclear DNA-like RNA by RNA-DNA hybridization. Proc. Nat. Acad. Sci. U.S.A. 58:320-327.

4. Bishop, J. O., and F. W. Robertson. 1969. Transcription of bacteriophage $\mathrm{T} 4$ deoxyribonucleic acid in vitro. Biochem. J. 115:353-361.

5. Bishop, J. O., F. W. Robertson, J. A. Burns, and M. Melli. 1969. Methods for the analysis of deoxyribonucleic acidribonucleic acid hybridization data. Biochem. J. 115:361370.

6. Bock, R. M. 1967. Controlled partial hydrolysis of RNA, p. 218-224. In L. Grossman and K. Moldave (ed.), Methods in enzymology, vol. XIIA. Academic Press Inc., New York.

7. Bolle, A., R. H. Epstein, W. Salser, and E. P. Geiduschek. 1968. Transcription during bacteriophage T4 development: synthesis and relative stability of early and late RNA. J. Mol. Biol. 31:325-348.

8. Brody, E. N., H. Diggelman, and E. P. Geiduschek. 1970. Transcription of the bacteriophage T4 template. Obligate synthesis of T4 prereplicative RNA in vitro. Biochemistry 9:1289-1299.

9. Brody, E. N., and E. P. Geiduschek. 1970. Transcription of the bacteriophage T4 template. Detailed comparison of in vitro and in vivo transcripts. Biochemistry 9:1300-1309.

10. Bruner, R., and R. E. Cape. 1970. The expression of two classes of late genes of bacteriophage T4. J. Mol. Biol. 53:69-89.

11. Carp, R. I., G. Sauer, and F. Sokol. 1969. The effect of actinomycin $D$ on the transcription and replication of simian virus 40 deoxyribonucleic acid. Virology 37:214-226.

12. Church, R. B., and B. J. McCarthy. 1968. Related base sequences in the DNA of simple and complex organisms. II The interpretation of DNA/RNA hybridization studies with mammalian nucleic acids. Biochem. Genet. 2:55-73.

13. Cohen, S. S. 1968. Virus-induced enzymes. Columbia University Press, New York.

14. Darnell, J. E. 1968. Ribonucleic acids from animal cells. Bacteriol. Rev. 32:262-290.

15. Eagle, H. 1955. Propagation in a fluid medium of a human epidermoid carcinoma, strain KB. Proc. Soc. Exp. Biol. Med. 89:362-364.

16. Eagle, H. 1959. Amino acid metabolism in mammalian cell cultures. Science 130:432-437.

17. Flanagan, J. F., and H. S. Ginsberg. 1962. Synthesis of virusspecific polymers in adenovirus-infected cells: effect of 5-fluorodeoxyuridine. J. Exp. Med. 116:141-157.

18. Friedman, M. P., M. J. Lyons, and H. S. Ginsberg. 1970. Biochemical consequences of type 2 adenovirus and simian virus $\mathbf{4 0}$ double infections of African green monkey kidney cells. J. Virol. 5:586-597.

19. Gage, L. P., and E. P. Geiduschek. 1967. Repression of early messenger transcription in the development of a bacteriophage. J. Mol. Biol. 30:435-439.

20. Geiduschek, E. P., D. L. Wilson, and L. P. Gage. 1969. Determinants of gene expression during viral development. J. Cell. Physiol. 74:(Suppl. 1)81-86.

21. Gilbert, W. 1963. Polypeptide synthesis in Escherichia coli. II. The polypeptide chain and s.RNA. J. Mol. Biol. 6:389-403.

22. Gillespie, D. 1968. The formation and detection of DNARNA hybrids, p. 641-668. In L. Grossman and K. Moldave (ed.), Methods in enzymology, vol. XIIB. Academic Press Inc., New York.

23. Gillespie, D., and S. Spiegelman. 1965. A quantitative assay for DNA-RNA hybrids with DNA immobilized in a membrane. J. Mol. Biol. 12:829-842.

24. Girard, M., H. Latham, S. Penman, and J. E. Darnell. 1965.
Entrance of newly formed messenger RNA and ribosomes into Hela cell cytoplasm. J. Mol. Biol. 11:187-201.

25. Green, M. 1962. Biochemical studies on adenovirus multiplication III. Requirement for DNA synthesis. Virology 18: 601-613.

26. Green, M. 1970. Oncogenic viruses, p. 701-756. In E. Snell, P. Boyer, A. Meister, and R. Sinsheimer (ed.), Annual reviews of biochemistry, vol. 39. Annual Reviews, Inc., Palo Alto.

27. Green, M., M. Pina, K. Fujinaga, S. Mak, and D. Thomas. 1968. Transcription of viral genes in adenovirus-infected and transformed cells, p. 15-37. In M. Pollard (ed.), Virusinduced immunopathology; perspectives in virology, vol. VI. Academic Press Inc., New York.

28. Green, M., M. Pina, R. Kimes, P. C. Wensink, L. A. MacHattie, and C. A. Thomas. 1967. Adenovirus DNA. I. Molecular weight and conformation. Proc. Nat. Acad. Sci. U.S.A. 57:1302-1309.

29. Hall, B. D., M. H. Green, A. P. Nygaard, and J. A. Bozel. 1963. The copying of DNA in T2-infected $E$. coli. Cold Spring Harbor Symp. Quant. Biol. 28:201-203.

30. Hall, B. D., A. P. Nygaard, and M. H. Green. 1964. Control of T2-specific RNA synthesis. J. Mol. Biol. 9:143-153.

31. Hall, B. D., and S. Speigelman. 1961. Sequence complementarity of T2-DNA and T2-specific RNA. Proc. Nat. Acad. Sci. U.S.A. 47:137-146.

32. Hansen, J. N., G. Spiegelman, and H. O. Halvorson. 1970. Bacterial spore outgrowth: its regulation. Science 168:12911298.

33. Homma, M., and A. F. Graham. 1963. Synthesis of RNA in $\mathbf{L}$ cells infected with mengo virus. J. Cell. Comp. Physiol 62:179-192.

34. Hudson, J., D. Goldstein, and R. Weil. 1970. A study on the transcription of the polyoma viral genome. Proc. Nat. Acad. Sci. U.S.A. 65:226-233.

35. Lavallé, R., and G. De Hauwer. 1968. Messenger RNA synthesis during amino acid starvation in Escherichia coli. J. Mol. Biol. 37:269-288.

36. Lawrence, W. C., and H. S. Ginsberg. 1967. Intracellular uncoating of type 5 adenovirus deoxyribonucleic acid. J. Virol. 1:851-867.

37. Lonberg-Holm, K., and L. Philipson. 1969. Early events of virus-cell interaction in an adenovirus system. J. Virol. 4:323-338.

38. McCarthy, B. J., and R. B. Church. 1970 . The specificity of molecular hybridization reactions, p. 131-150. In E. Snell, P. Boyer, A. Meister, and R. Sinsheimer (ed.) Annual reviews of biochemistry, vol. 39. Annual Reviews, Inc. Palo Alto.

39. Matsukage, A., and T. Minagawa. 1967. Shut-off of early messenger RNA synthesis in $E$. coli infected with phage T2. Biochem. Biophys. Res. Commun. 29:39-43.

40. Melli, M., and J. O. Bishop. 1969. Hybridization between rat liver DNA and complementary RNA. J. Mol. Biol. 40:117136.

41. Nygaard, A. P., and B. D. Hall. 1963. A method for the detection of RNA-DNA complexes. Biochem. Biophys. Res. Commun. 12:98-104.

42. Oda, K., and R. Dulbecco. 1968. Regulation of transcription of the SV 40 DNA in productively infected and in transformed cells. Proc. Nat. Acad. Sci. U.S.A. 60:525-532.

43. Oda, K., and W. K. Joklik. 1967. Hybridization and sedimentation studies on "early" and "late vaccinia messenger RNA. J. Mol. Biol. 27:395-419.

44. Pina, M., and M. Green. 1969. Biochemical studies on adenovirus multiplication. XIV. Macromolecule and enzyme synthesis in cells replicating oncogenic and nononcogenic human adenoviruses. Virology 38:573-586.

45. Russell, W. C., K. Hayashi, P. J. Sanderson, and H. G. Pereira. 1967. Adenovirus antigens-a study of their properties and sequential development in infection. J. Gen. Virol. 1:495-507. 
46. Salser, W., A. Bolle, and R. Epstein. 1970. Transcription during bacteriophage $\mathrm{T} 4$ development: a demonstration that distinct subclasses of the "early" RNA appear at different times and that some are "turned off" at late times. J. Mol. Biol. 49:271-295.

47. Scherrer, K., and J. E. Darnell. 1962. Sedimentation characteristics of rapidly labeled RNA from Hela cells. Biochem. Biophys. Res. Commun. 7:486-490.

48. Soeiro, R., and J. E. Darnell. 1969. Competition hybridization by "presaturation" of Hela cell DNA. J. Mol. Biol. 44:551562.

49. Stubbs, J. D., and B. D. Hall. 1968. Level of tryptophan messenger RNA in Escherichia coli. J. Mol. Biol. 37:289-302.

50. Thomas, D. C., and M. Green. 1966. Biochemical studies on adenovirus multiplication. XI. Evidence of a cytoplasmic site for the synthesis of viral-coded proteins. Proc. Nat Acad. Sci. U.S.A. 56:243-246.

51. Thomas, D. C., and M. Green. 1969. Biochemical studies on adenovirus multiplication. XV. Transcription of the adenovirus type 2 genome during productive infection. Virology 39:205-210.

52. Velicer, L. F., and H. S. Ginsberg. 1968. Cytoplasmic synthesis of type 5 adenovirus capsid proteins. Proc. Nat. Acad. Sci. U.S.A. 61:1264-1271.

53. Velicer, L. F., and H. S. Ginsberg. 1970. Synthesis, transport, and morphogenesis of type 5 adenovirus capsid proteins. J. Virol. 5:338-352.

54. Warocquier, R., J. Samaille, and M. Green. 1969. Biochemical studies on adenovirus multiplication. XVI. Transcription of the adenovirus genome during abortive infection at elevated temperatures. J. Virol. 4:423-428. 